\title{
The effect of surface morphology on endothelial and smooth muscle cells growth on blow-spun fibrous scaffolds
}

\author{
Iwona Łopianiak', Michał Wojasiński ${ }^{1}$, Aleksandra Kuźmińska' ${ }^{1}$ Paulina Trzaskowska² and Beata A. Butruk-Raszeja ${ }^{1 *}$
}

\begin{abstract}
This study aimed to analyze the growth of two types of blood vessel building cells: endothelial cells (ECs) and smooth muscle cells (SMCs) on surfaces with different morphology. Two types of materials, differing in morphology, were produced by the solution blow spinning technique. One-layer materials consisted of one fibrous layer with two fibrous surfaces. Bi-layer materials consisted of one fibrous-solid layer and one fibrous layer, resulting in two different surfaces. Additionally, materials with different average fiber diameters (about 200, 500, and $900 \mathrm{~nm}$ ) were produced for each group. It has been shown that it is possible to obtain structures with a given morphology by changing the selected process parameters (working distance and polymer solution concentration). Both morphology (solid versus fibrous) and average fiber diameter (submicron fibers versus microfibers) of scaffolds influenced the growth of ECs. However, this effect was only visible after an extended period of culture (6 days). In the case of SMCs, it was proved that the best growth of SMCs is obtained for micron fibers (with an average diameter close to $900 \mathrm{~nm}$ ) compared to the submicron fibers (with an average diameter below $900 \mathrm{~nm}$ ).
\end{abstract}

Keywords: One-layer vascular graft, Bi-layer vascular graft, Solution blow spinning, Polyurethane, Endothelial cells, Smooth muscle cells

\section{Introduction}

Cardiovascular diseases (CVDs), classified as civilization diseases, are currently the major cause of death globally [1]. Among them, coronary heart disease and peripheral arterial disease are the most common and dangerous for human life [2]. In advanced stages, these diseases lead to heart attacks or strokes caused by the complete clogging of the blood vessels. Coronary artery bypass grafting is one of the treatment methods of advanced ischemic heart disease. Patients' autologous blood vessels (e.g., saphenous veins) are currently the most frequently used as bypasses [3, 4]. However, in many cases, the poor

\footnotetext{
* Correspondence: Beata.Raszeja@pw.edu.pl

${ }^{1}$ Laboratory of Biomedical Engineering, Faculty of Chemical and Process

Engineering, Warsaw University of Technology, Waryńskiego 1, 00-645 Warsaw, Poland

Full list of author information is available at the end of the article
}

condition of the patient's vein makes it impossible to use for transplant. Moreover, there are problems with the long-term patency of the transplanted blood vessel, which necessitates the need for further surgical interventions $[5,6]$. The low availability of autologous blood vessels and problems after implantation generate the need to look for other solutions to save patients' health and life [7]. An alternative solution is synthetic polymer prostheses that imitate the structure, functions, and properties (mechanical and morphological) of native vessels $[8,9]$. Meaning that prostheses' porous structure and appropriate mechanical properties should provide proper conditions for cells to infiltrate the prosthesis, proliferate and grow $[10,11]$.

Two types of cells: endothelial cells (ECs) and smooth muscle cells (SMCs), build native blood vessels. Mimicking the blood vessel layered structure is an essential 
aspect during vascular prostheses designing. The inner layer should promote the formation of the endothelium, enable oxygen and nutrients transport, and prevent the migration of cells through this layer. In contrast, the outer layer should allow the migration of SMCs inside the prosthesis structure [12].

Previous studies show that among the numerous factors determining the proper development and activity of cells, one of the most important is the surface morphology. In the case of fibrous materials, the fiber diameter and the pore size seem to be crucial. According to the results presented by other authors, fibers with diameters $<1 \mu \mathrm{m}$ are optimal for endothelial cells' growth. Ju et al. showed that endothelial cells growing on nanofibers (approx. fiber diameter $=270 \mathrm{~nm}$ ) presented numerous actin fibers and formed stronger focal adhesion contacts than those growing on microfibers [12]. Similar results were presented by others [13]. The diameter of the fibers also influences the development of SMCs. It has been shown that increasing fiber diameter reduced SMC proliferation and increased SMC infiltration [14]. In turn, studies have shown that reducing the diameter of the fibers accelerates the proliferation and maturation of SMCs [15]. Finally, pore size is crucial parameter during neotissue formation[16]. The answer to these diverse needs is the creation of layered prosthesis in which the properties of the inner and outer layers are different, in order to better support the development of a specific type of cells.

Work by Goins et al. review techniques used in the production of layered vascular prostheses [17]. Techniques for fabrication of layered prosthesis are mainly based on electrospinning (ES) [18-21]. In addition, various processes combining ES and other techniques have been proposed: melt electrowriting [22], knitting [23], phase separation [24]. Compared to ES, solution blow spinning (SBS) technique is distinguished by several advantages, i.e. a simpler system, not requiring the use of electric voltage, and higher production efficiency, which is especially important in the case of multi-layer structures production with a thickness of up to several hundred micrometers. So far, it has been proposed to modify the internal prosthesis by applying the blow spun fibers [25]. Also, layered prosthesis produced by SBS combined with dip spinning [26] were produced.

In this paper, one- and bi-layer fibrous materials with different fiber diameters were fabricated using only one technique - SBS. In contrast to the above-mentioned works, based on ES or mixed techniques, we propose a simple SBS-based process that allows to control the critical parameters of the manufactured prosthesis, i.e. the average diameter of the fibers, the number and thickness of layers in the prosthesis' wall. Obtaining the appropriate product is possible thanks to the change of basic process parameters, i.e. working distance, concentration of the polymer solution. The presented technology is the subject of a patent. Medical-grade polyurethane was used as a polymer of choice, due to its relatively high hemocompatibility.

Three groups of materials differing in average fiber diameter (about 200, 500 and $900 \mathrm{~nm}$ ) and two groups of materials with different structures (one-layer and bilayer) were produced. One-layer (1L) scaffolds consisted of one fibrous layer. Bi-layer (2L) scaffolds consisted of one fibrous-solid layer and one fibrous layer. After characterizing the physical and mechanical properties of the obtained structures, the influence of surface morphology on the growth of ECs and SMCs was examined. ECs were seeded on the surface marked as inner (IS, collector side). The opposite surface, labeled as the outer (OS), served as the surface for SMCs growth. The analysis of cell growth allowed for selecting the most favorable surfaces for the growth of both types of cells, which will allow for the appropriate design of the structure of the blow-spun vascular prosthesis.

The main goal of this study was to analyze the various morphological types of surfaces obtained with the SBS technique. In particular, we focused on the influence of morphology on the growth of ECs and SMCs. The presumed result was the selection of materials that present high coverage of ECs and high infiltration of SMCs. The selected surfaces will enable further, more detailed work, i.e. cell cultures in flow, analysis of specific cell activity markers.

\section{Materials and methods Scaffold fabrication}

Polyurethane (ChronoFlex C75A, AdvanSource Biomaterials) nano/microfibrous materials in the form of cylindrical scaffolds were produced in the SBS process, described in detail elsewhere [27]. Here, 1,1,1,3,3,3-hexafluoro-2-propanol ( $>99.0 \%$, TCI Chemicals) was used as a solvent. Polymer solutions were prepared overnight in concentrations of 2,4 , and $5 \% \mathrm{w} / \mathrm{w}$. To produce nano/ microfibrous materials, each polyurethane solution was supplied through the inner nozzle of the concentric nozzles system in the SBS apparatus with a constant flow rate of $30 \mathrm{ml} / \mathrm{h}$. Simultaneously, the airstream was supplied through the outer nozzle of the SBS nozzles system with a pressure of $0.1 \mathrm{MPa}$. Fibers were produced by shear-drag elongation of the polymer solution by the stream of air on the distance between the nozzles system and the surface of the collector (working distance). Nano/microfibrous materials were prepared as one-layer materials and bi-layer materials. One-layer scaffolds were produced using a $30 \mathrm{~cm}$ working distance. Bi-layer scaffolds were produced by changing working distance during the process. The first layer was produced using a 
$10 \mathrm{~cm}$ working distance and by blowing $20 \%$ of the total polymer solution volume. The second layer was produced using a $30 \mathrm{~cm}$ working distance and by blowing $80 \%$ of the total polymer solution volume. The volume of polymer solution for the scaffold production was adjusted to fabricate cylindrical scaffolds with wall thickness in the range from 300 to $500 \mu \mathrm{m}$. Detailed process parameters are presented in Table 1 . The rotating cylinder (cylinder diameter: $3 \mathrm{~mm}$, length: $120 \mathrm{~mm}$, rotational speed: $3000 \mathrm{rpm}$ ) was used as a collector. Cylindrical samples were pulled off the collector and kept in ventilated containers overnight to ensure complete solvent evaporation. For microscopic analyzes and cell culture, cylindrical samples were cut open and flattened. The inner surface of the cylinder (from the collector side) was marked as IS, while the opposite outer surface was marked as OS.

\section{Scaffold characterization \\ Fiber diameter, pore size}

Rectangular samples were subjected to scanning electron microscopy (SEM, Phenom G1, PhenomWorld). Samples were coated with a $15 \mathrm{~nm}$ layer of gold/palladium alloy $(80 / 20$ at\%) using a sputter coater (K550 Emitech, Quorum Technologies). Ten randomly selected spots were photographed with 5000x magnification, and the images were used for fiber diameter and pore size measurements. All measurements were performed using Fiji software [28]. Results are presented as fiber size distributions $(n=100)$, mean fiber diameter, standard deviation, minimum and maximum fiber diameter. Pore sizes were measured using the same images, and mean pore size $(n=100) \pm$ standard deviation is reported. Microscopic analysis was performed for both surfaces of cylindrical scaffolds (OS and IS).

\section{Surface wettability}

Materials in the form of cylinders were cut open to obtain flat mats. Both the inner (IS) and outer (OS) surfaces were subjected to wettability analysis. Samples were glued to a glass slide, and a drop of distilled water $(5 \mu \mathrm{l})$ was placed on a clean and dry surface. The contact angle was measured automatically using Kruss DSA 100 software; the measurement was performed in at least 10 randomly selected spots on analyzed material. Each material variant was tested in triplicate $(n=30)$.

\section{Porosity}

The porosity of all types of polyurethane cylindrical scaffolds was measured using the gravimetric method, described in detail elsewhere [29]. In general, the thickness of each sample $(n=25)$ was measured based on the SEM images of scaffolds cross-section $(n=5)$, and then the volume of the sample $\left(\mathrm{V}_{\mathrm{s}}\right)$ was calculated (inner diameter of the scaffold was $3 \mathrm{~mm})$. Each sample $(n=5)$ was weighted $\left(m_{s}\right)$, and the apparent density $\left(\rho_{\text {app }}\right)$ for all samples was calculated using the following equation: $\rho_{a p p}=m_{s} \cdot V_{s}^{-1}$ $\left[\mathrm{g} / \mathrm{cm}^{3}\right]$. Then, the scaffold porosity $(\varepsilon, n=5)$ was calculated using the following equation: $\varepsilon=1-\rho_{\mathrm{app}} \cdot \rho_{\mathrm{p}}{ }^{-1}$, where $\rho_{\mathrm{p}}-$ polyurethane density $\left(1.2 \mathrm{~g} / \mathrm{cm}^{3}\right)$ [30].

\section{Mechanical properties}

Cylindrical samples $(3 \mathrm{~mm}$ inner diameter, $70 \mathrm{~mm}$ length) of fibrous scaffolding materials underwent a uniaxial stretching test according to protocols established based on ASTM standards (Designation: D 882-02 and D 638-02a). The experiment was conducted using an Instron 3345 model with pneumatic jaws within $50 \mathrm{~mm}$ of each other. The $10 \mathrm{~mm}$ long tips of samples were placed in the pneumatic jaws of the testing machine, so that the central part of the sample (50 mm length) was stretched with crosshead speed $5 \mathrm{~mm} \cdot \mathrm{min}^{-1}$ at room

Table 1 Parameters of the SBS process applied during material fabrication. The numbers in brackets correspond to the volumes of polymer solution used to produce the first and the second layer in bi-layer scaffolds

\begin{tabular}{|c|c|c|c|c|}
\hline Sample & $\begin{array}{l}\text { Polymer solution } \\
\text { concentration }[\% \mathrm{w} / \mathrm{w}]\end{array}$ & $\begin{array}{l}\text { Number of } \\
\text { layers [-] }\end{array}$ & $\begin{array}{l}\text { Polymer solution volume (1st layer/ } \\
\text { 2nd layer) [ml] }\end{array}$ & $\begin{array}{l}\text { Working distance (1st layer } / 2 \mathrm{nc} \\
\text { layer) }[\mathrm{cm}]\end{array}$ \\
\hline $\begin{array}{l}\text { C75A_1L_ } \\
200\end{array}$ & 2 & 1 & 20 & 30 \\
\hline $\begin{array}{l}\text { C75A_1L_ } \\
500\end{array}$ & 4 & 1 & 5 & \\
\hline $\begin{array}{l}\text { C75A_1L_ } \\
900\end{array}$ & 5 & 1 & 5 & \\
\hline $\begin{array}{l}\text { C75A_2L_ } \\
200\end{array}$ & 2 & 2 & $20(4 / 16)$ & $10 / 30$ \\
\hline $\begin{array}{l}\text { C75A_2L_ } \\
500\end{array}$ & 4 & 2 & $5(1 / 4)$ & \\
\hline $\begin{array}{l}\text { C75A_2L_ } \\
900\end{array}$ & 5 & 2 & $5(1 / 4)$ & \\
\hline
\end{tabular}


temperature and humidity. Load-strain curves were recorded, as were the maximum load and strain at rupture. It is emphasized that according to porosity measurements and SEM images, only a fraction of each sample thickness is occupied with fibers (1- $\varepsilon$ ), which implies that the applied load is supported by only such a fraction of the sample's thickness. This effect was accounted for in the data processing for maximum stress calculation. For each type of scaffold, results of Young's modulus, elongation at break, and tensile strength are presented as mean values \pm standard deviation $(n=5)$.

\section{Cell culture}

All materials before culture were placed in a $1 \% \mathrm{v} / \mathrm{v}$ antibiotic/antimycotic solution $(100 \mathrm{U} / \mathrm{ml}$ penicillin G, $100 \mu \mathrm{g} / \mathrm{ml}$ streptomycin sulfate, and $0.25 \mu \mathrm{g} / \mathrm{ml}$ amphotericin B) diluted in sterile phosphate-buffered saline (PBS) for $24 \mathrm{~h}$ at $4{ }^{\circ} \mathrm{C}$ for sterilization. Then, scaffolds were washed three times with sterile deionized water on a roller for $5 \mathrm{~min}$ each time.

ECs (ATCC) were cultured at $37{ }^{\circ} \mathrm{C}$ in a $5 \% \mathrm{CO}_{2}$ humidified atmosphere using MCDB-131 medium with phenol red and supplemented with $10 \%$ fetal bovine serum (ATCC), 1\% penicillin-streptomycin (Gibco), 10 $\mathrm{mM}$ L-glutamine (Gibco), $1 \mu \mathrm{g} / \mathrm{ml}$ hydrocortisone
(Sigma-Aldrich) and $10 \mathrm{ng} / \mathrm{ml}$ endothelial growth factor (Life Technologies).

SMCs (Lonza) were cultured in an incubator $\left(37{ }^{\circ} \mathrm{C}\right.$, $5 \% \mathrm{CO}_{2}$ humidified atmosphere). Cells were grown in Smooth Muscle Cell Growth Medium 2 (PromoCell), supplemented with fetal calf serum $(0.05 \mathrm{ml} / \mathrm{ml})$, epidermal growth factor $(0.5 \mathrm{ng} / \mathrm{ml})$, basic fibroblast growth factor $(2 \mathrm{ng} / \mathrm{ml})$, insulin $(5 \mu \mathrm{g} / \mathrm{ml})$.

Sterile scaffolds were placed in the 24-well plates, mounted with inserts, and incubated with medium for $1 \mathrm{~h}$ at $37{ }^{\circ} \mathrm{C}$. Cells (ECs or SMCs) were harvested, seeded on the material at the seeding density of $1 \times$ $10^{5}$ cells $/ \mathrm{ml}$, and cultured at $37{ }^{\circ} \mathrm{C}$ in a $5 \% \mathrm{CO}_{2}$ humidified atmosphere. Cultures with different types of cells were carried out on different surfaces of the scaffolds (Fig. 1). ECs were cultured on the inner surface of scaffolds (IS), whereas SMCs were cultured on the outer surface (OS).

\section{Cell viability}

ECs viability was tested using alamarBlue ${ }^{\mathrm{TM}}$ assay (Thermo Fisher Scientific) according to the manufacturer's protocol. Cells were seeded on materials' surfaces as described above. Cells cultured in wells with no material (seeding density $=1 \times 10^{5}$ cells $/ \mathrm{ml}$ ) were used as a control for viability calculation. After $1 \mathrm{~d}$ and $7 \mathrm{~d}$ of

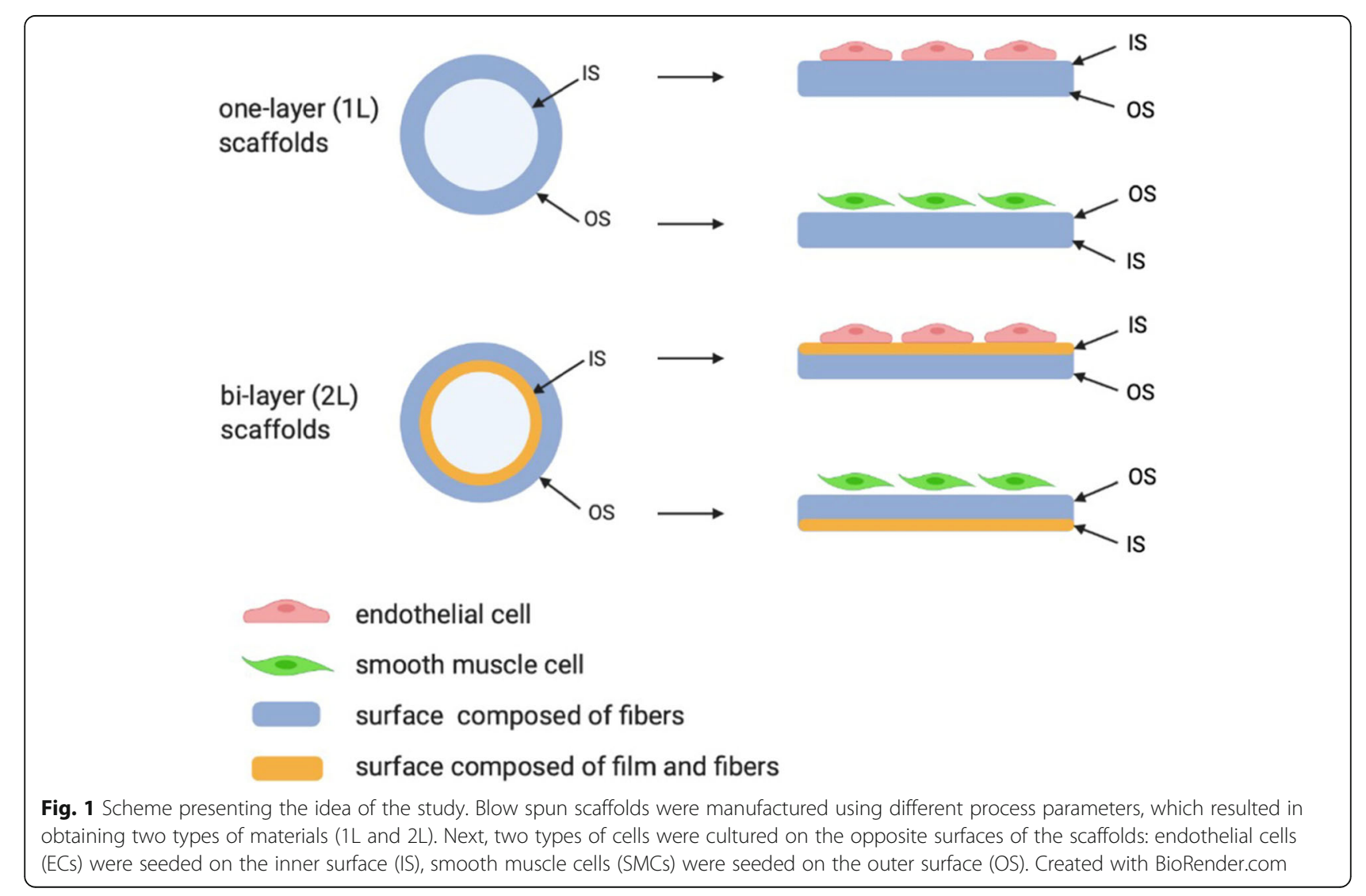


culture, the medium was removed from wells, and $500 \mu \mathrm{l}$ of alamarBlue ${ }^{\mathrm{TM}}$ working solution (alamarBlue ${ }^{\mathrm{TM}}$ reagent 10x diluted in fresh DMEM without phenol red) was added $(500 \mu \mathrm{l} / \mathrm{well})$. Materials were incubated for $4 \mathrm{~h}$ at $37{ }^{\circ} \mathrm{C}$ in a $5 \% \mathrm{CO}_{2}$ humidified atmosphere (protected from light). Following incubation, $100 \mu \mathrm{l}$ of alamarBlue ${ }^{\mathrm{TM}}$ solution was transferred in triplicate to a 96well plate (black), and fluorescence (Ex. $=550 \mathrm{~nm}$, Em. $=590 \mathrm{~nm}$ ) was measured. Samples were washed with PBS (3x, 5 min on a plate shaker), incubated with fresh DMEM, and used for further viability measurements. Viability results are presented as the percentage of positive control according to the equation:

$$
\begin{aligned}
\operatorname{Viability}(\%)= & \left(\mathrm{FI} \mathrm{sample}_{\mathrm{t}=\mathrm{n}} / \mathrm{FI} \mathrm{control}_{\mathrm{t}=1}\right) \\
& \bullet 100 \%,
\end{aligned}
$$

where:

FI sample - fluorescence intensity of the sample after "n" days of culture,

FI control - fluorescence intensity of the control after 1 day of culture.

\section{$\mathrm{LDH}$ release}

$\mathrm{LDH}$ release during ECs culture was evaluated using CyQUANT $^{\mathrm{TM}}$ LDH Cytotoxicity assay (Thermo Fisher Scientific) according to the manufacturer's setup. ECs were seeded on the materials as described above. After 1 d, $3 \mathrm{~d}$, and $7 \mathrm{~d}$ of culture, $50 \mu \mathrm{l}$ MCDB- 1 medium from over the material was transferred to 96-well plate triplicate, and LDH reagent (Substrate Mix) was added. After $30 \mathrm{~min}$ of incubation at room temperature, stop solution was added, and absorbance (490 nm and $680 \mathrm{~nm}$ ) was measured. The medium was changed $24 \mathrm{~h}$ before the test each time. The LDH release was calculated as a percentage of LDH released from control, according to the equation:

$$
\begin{aligned}
\mathrm{LDH} \text { release }(\%)= & \left(\text { Abs sample }_{\mathrm{t}=\mathrm{n}} / \mathrm{Abs} \mathrm{control}_{\mathrm{t}=1}\right) \\
& \bullet 100 \%,
\end{aligned}
$$

where:

Abs sample - absorbance of the sample after "n" days of culture,

Abs control - absorbance of the control after 1 day of culture.

\section{Collagen secretion}

Collagen I alpha 1 ELISA Kit (ab210966, Abcam) was used to measure collagen secretion during SMCs culture. SMCs were seeded as described above. On the given day of culture (D1, D5, D7, D10, D14), the medium was collected from the materials, centrifuged at
$2000 \mathrm{x} \mathrm{g}$ for $10 \mathrm{~min}$, and diluted 1: 4 with Sample Diluent. Solutions were stored at $-20{ }^{\circ} \mathrm{C}$ until samples from all time points were collected. The test was performed according to the manufacturer's instructions. Briefly, $50 \mu \mathrm{l}$ of the sample and $50 \mu \mathrm{l}$ of the Antibody Cocktail were added to a well of a 96-well plate and incubated for $1 \mathrm{~h}$ at RT. After this time, each well was washed $3 \times$ $350 \mu \mathrm{l} 1 \mathrm{X}$ Wash Buffer. Then $100 \mu \mathrm{l}$ of TMB Development Solution was added to each well, incubated in the dark for $10 \mathrm{~min}$. Finally, $100 \mu \mathrm{l}$ of Stop Solution was added to each well, and the plate was shaken for $1 \mathrm{~min}$. Absorbance was measured at $450 \mathrm{~nm}$. The amount of released collagen was calculated based on the standard curve equation prepared from the standards provided in the kit.

\section{Cell adhesion}

The number of surface-adhered cells was calculated using a confocal microscope (LSM 880, Zeiss) equipped with ZEISS ZEN software (Zen 2). After a given time of culture, samples were washed with PBS $(4 \mathrm{x}, 5 \mathrm{~min}$ on a plate shaker) and fixed with $4 \% \mathrm{w} / \mathrm{v}$ paraformaldehyde (Sigma-Aldrich, $500 \mu \mathrm{l} /$ well). Plates were incubated at $4{ }^{\circ} \mathrm{C}$ for $24 \mathrm{~h}$ and washed with PBS ( $3 x, 5$ min on a plate shaker). Then cells were permeabilized by adding $500 \mu \mathrm{l} /$ well of $0.2 \%$ Triton X-100 for $8 \mathrm{~min}$. Materials were washed with PBS ( $4 \mathrm{x}, 5 \mathrm{~min}$ on a plate shaker). Next, materials were incubated with AlexaFluor 488 (300 $\mu \mathrm{l} /$ well, ThermoFisher Scientific) for $1 \mathrm{~h}$ in the dark, washed with PBS (4x, $5 \mathrm{~min}$ on a plate shaker), and incubated with 300nM DAPI $(300 \mu \mathrm{l} /$ well, ThermoFisher Scientific) at room temperature for $6 \mathrm{~min}$ in the dark. Finally, samples were washed with PBS $(4 \mathrm{x}, 5 \mathrm{~min}$ on a plate shaker), placed on microscope slides with a drop of glue (ProLong Diamond Antifade Mountant, Invitrogen), covered with cover slides and observed using the confocal microscope. Cell nuclei were stained with DAPI dye. Images in magnification 20x were taken for each type of sample $(n=6)$. Cell number per $\mathrm{mm}^{2}$ and cell coverage (calculated as the ratio of the area occupied by the cells to the area of the sample) were counted using Fiji software [28] based on the number of visible nuclei (cell number) or area of actin-stained cells (cell coverage). SMCs infiltration was calculated from CLSM images using Zeiss software and $\mathrm{z}$-stacking function.

\section{Statistical analysis}

Statistical significance of differences was analyzed using single-factor analysis of variance (ANOVA) for $p<0.05$ with post hoc Tukey's test (OriginPRO 2020b). 


\section{Results}

\section{Scaffold characterization} Morphology

Figure 1 summarizes the idea of the study. All materials were obtained in the form of cylindrical scaffolds in which the inner (collector side, IS) and outer (OS) surfaces were distinguished. Cells were grown on different sides of the scaffold surfaces, depending on the cells analyzed: ECs on the inner surface and SMCs on the outer surface. ECs were cultured on six types of material, differing in morphology (one-layer and bi-layer) and an average fiber diameter (designated as C75A_1L_200, C75A_1L_500 and C75A_1L_900, C75A_2L_200, C75A 2L_500 and C75A_2L_900). As the outer surface (OS) for $1 \mathrm{~L}$ - and $2 \mathrm{~L}$-type materials were produced in the same way, SMCs were cultured only on three types of material differing in average fiber diameter (designated as C75A_200, C75A_500, and C75A_900).

Materials were made in two morphological variants: a one-layer (1L) and a bi-layer (2L) and Table 2 lists the material variants analyzed in the study. A homogeneous fibrous structure in cross-section characterized 1L-type materials - both surfaces (IS and OS) consisted of fibers of similar morphology. A structure variety in crosssection characterized 2L-type materials - the outer layer (OS) was made of fibers, while the inner surface (IS) was made of mixed fibrous and solid areas. Bi-layer scaffolds were obtained in one two-step SBS process. It was possible thanks to the use of the variable nozzle-collector working distance: shorter $(10 \mathrm{~cm})$ during the production of the first layer and longer $(30 \mathrm{~cm})$ during the production of the second layer. Additionally, three different polymer concentrations were used to obtain three different size groups of fibers within each material group. The concentrations of polymer were selected to obtain fibers with an average diameter in the range of 200-300 $\mathrm{nm}$ (1L_200, 2L_200), 500-600 nm (1L_500, 2 L_500), and 900-1000 nm (1L_900, 2L_900).

Figures 2 and 3 show the morphology of 1L-type and 2L-type materials. It was possible to produce fibers in the assumed diameter ranges: $200-300 \mathrm{~nm}$ for a polymer concentration of $2 \% \mathrm{w} / \mathrm{w}, \quad 500-600 \mathrm{~nm}$ for a concentration of $4 \% \mathrm{w} / \mathrm{w}$, and $900-1000 \mathrm{~nm}$ for a concentration of $5 \% \mathrm{w} / \mathrm{w}$. In the case of $1 \mathrm{~L}$-type materials, the inner surface was characterized by the presence of local defects in the form of solid, non-fibrous areas. The number of such defects was higher on materials made from the lowest polymer concentration (C75A_1L_200). The number of defects on the outer surface of the materials was much smaller. Figure 2 also shows a crosssection of the obtained materials. It can be noticed that the materials show a homogeneous fibrous structure along the cross-section, while local defects in the form of solid areas appear on the inner surface. In the case of $2 \mathrm{~L}$ materials (Fig. 3), the inner surface mostly showed a solid structure (film), with local areas composed of fibers with the average diameters depending on the polymer concentration used in the process. The outer surface was made of fibers, and it appears to have the same structure as both surfaces in the case of 1L-type materials. SEM images of the cross-sections show a change in the structure along the cross-section - on the inner surface, there is a thin layer of solid film, then the material changes into a fibrous structure. For both types of scaffolds $(1 \mathrm{~L}$ and $2 \mathrm{~L})$, the material thickness is similar, and it remains in the $300-500 \mu \mathrm{m}$ range.

Figure 4A presents histograms of fiber diameter distribution. As expected, the average fiber diameter increases as the polymer solution concentration increases. Also, the average fiber diameter obtained for the different polymer solution concentrations was statistically different $(p<0.001)$. For one-layer structures, these values are respectively: $232 \pm 89$ $\mathrm{nm}$ (C75A_1L_200), $524 \pm 15 \mathrm{~nm}$ (C75A_1L_500) and 936 \pm 302 nm (C75A_5_1L_900). The average fiber diameters obtained for bi-layer structures are similar: $245 \pm 90 \mathrm{~nm}$ (C75A_2L_200), $572 \pm 140$ nm (C75A_2L_500), $987 \pm 287$ nm (C75A_2L_900). No statistically significant differences were found between the average fiber diameter for analogous materials from the $1 \mathrm{~L}$ - and $2 \mathrm{~L}$-type group.

As the polymer solution concentration increases, the values of minimum $\left(\mathrm{d}_{\min }\right)$ and maximum $\left(\mathrm{d}_{\max }\right)$ diameter also increases. Narrow diameter distributions were obtained from the polymer solution with the lowest concentration $(2 \% \mathrm{w} / \mathrm{w})$. This result was obtained for both,

Table 2 Material variants analyzed in the study

\begin{tabular}{lllll}
\hline Sample & Polymer solution concentration [\% w/w] & Number of layers [-] & Inner surface (IS) & Outer surface (OS) \\
\hline C75A_1L_200 & 2 & 1 & fibers & fibers \\
C75A_1L_500 & 4 & 1 & fibers & fibers \\
C75A_1L_900 & 5 & 1 & fibers & fibers \\
C75A_2L_200 & 2 & 2 & film/fibers & fibers \\
C75A_2L_500 & 4 & 2 & film/fibers & fibers \\
C75A_2L_900 & 5 & 2 & film/fibers & fibers \\
\hline
\end{tabular}




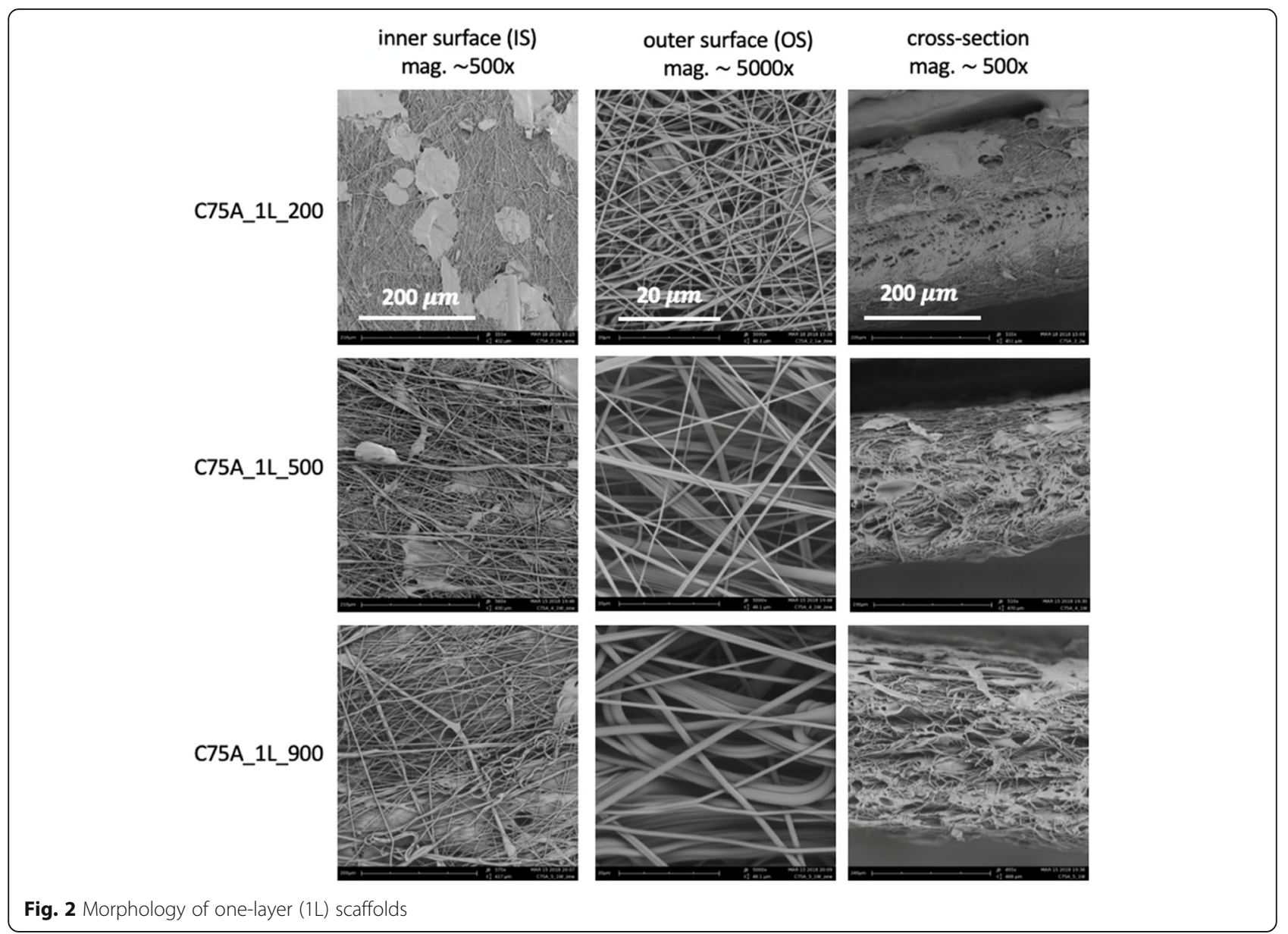

one-layer and bi-layer structure. $\mathrm{d}_{\min }$ values were respectively $97 \mathrm{~nm}$ (C75A_1L_200) and $81 \mathrm{~nm}$ (C75A_2L_ 200). $d_{\max }$ values were $493 \mathrm{~nm}$ (C75A_1L_200) and 636 nm (C75A_2L_200) respectively. Samples obtained from a $4 \% \mathrm{w} / \mathrm{w}$ polymer solution were characterized by a wider range of fiber diameters. $d_{\text {min }}$ values were $158 \mathrm{~nm}$ (C75A_1L_500) and $310 \mathrm{~nm}$ (C75A_2L_500). $\mathrm{d}_{\max }$ values were $1133 \mathrm{~nm}$ (C75A_1L_500) and 1054 nm (C75A_2L_500). The widest diameter distribution was obtained for the material obtained from a $5 \% \mathrm{w} / \mathrm{w}$ polymer solution. $d_{\min }$ values were $434 \mathrm{~nm}$ (C75A_1L_900) and $399 \mathrm{~nm}$ (C75A_2L_900). $\mathrm{d}_{\max }$ values were $1705 \mathrm{~nm}$ (C75A_1L_900) and $1829 \mathrm{~nm}$ (C75A_2L_900).

Figure 4B presents pore size distribution. There were no significant differences between one- and bi-layer structures. As expected, the average pore size increases as the average fiber diameter increases, however only for the group with the lowest average fiber diameter, the average pore size was significantly different from other groups $(p<0.001)$. For materials with an average fiber diameter of about $200 \mathrm{~nm}$, the average pore size was approximately $2 \mu \mathrm{m}$ (C75A_1L_200: $2.2 \pm 0.9 \mu \mathrm{m}$, C75A_2L_200: $2.2 \pm 0.7 \mu \mathrm{m})$. For these materials, the minimum pore size was slightly above $1 \mu \mathrm{m}$ (C75A_1L_200: $1.1 \mu \mathrm{m}, \mathrm{C} 75 \mathrm{~A}$ 2L_200: $1.1 \mu \mathrm{m})$. The maximum pore size was less than $10 \mu \mathrm{m}$ (C75A_1L_200: $6.6 \mu \mathrm{m}$, C75A_2L_200: $4.8 \mu \mathrm{m})$. For materials with average fiber diameter in the 500-600 $\mathrm{nm}$ range, the average pore size was approximately $5 \mu \mathrm{m}$ (C75A_1L_500: $4.8 \pm 2.5 \mu \mathrm{m}$, C75A_2L_500: $4.6 \pm$ $1.9 \mu \mathrm{m})$. The minimum pore size was above $1 \mu \mathrm{m}\left(\mathrm{C}^{2} 5 \mathrm{~A}_{-}\right.$ 1L_500: $1.3 \mu \mathrm{m}$, C75A_2L_500: $1.7 \mu \mathrm{m}$ ).

The maximum pore size has exceeded the value of $10 \mu \mathrm{m}$ (C75A_1L_500: $\left.12.0 \mu \mathrm{m}, \mathrm{C} 75 \mathrm{~A} \_2 \mathrm{~L} \_500: 10.0 \mu \mathrm{m}\right)$. Similar pore size values were obtained for materials with the highest average fiber diameter $(900-1000 \mathrm{~nm})$. The average pore size or those materials was also approximately $5 \mu \mathrm{m}$ (C75A_1L_900: $5.2 \pm 2.4 \mu \mathrm{m}$, C75A_2L_900: $5.4 \pm 2.6 \mu \mathrm{m})$. The minimum pore size was slightly above $1 \mu \mathrm{m}$ (C75A_1L_900: $1.0 \mu \mathrm{m}$, C75A_2L_900: $1.3 \mu \mathrm{m})$. The maximum pore size exceeded the value of $10 \mu \mathrm{m}(\mathrm{C} 75 \mathrm{~A}$ 1L_900: $13.6 \mu \mathrm{m}$, C75A_2L_900: $12.7 \mu \mathrm{m}$ ).

\section{Surface wettability}

The results of water contact angle (WCA) measurement are shown in Table 3. All analyzed surfaces were hydrophobic $\left(\mathrm{WCA}>90^{\circ}\right)$. 


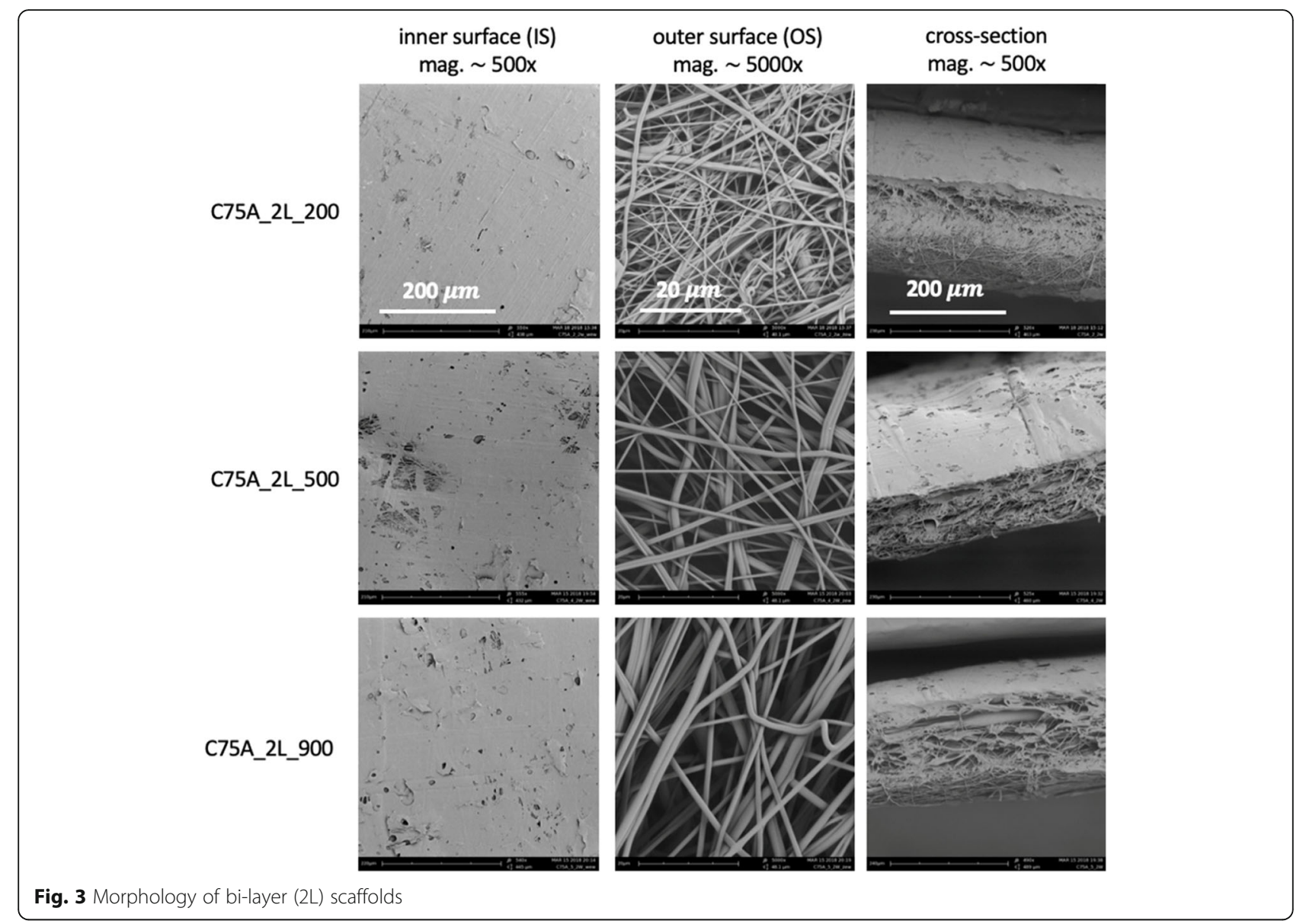

The outer surface (OS) showed similar wettability values for all tested variants (above $120^{\circ}$ ). There were no statistically significant differences in the WCA values for analogous materials from the $1 \mathrm{~L}$ - and $2 \mathrm{~L}$-type groups. This was expected since the outer surface is produced in the same way in both groups. There was no relationship between the value of WCA and the average diameter of the fibers building the surface - similar values were obtained for both surfaces composed of micron and submicron fibers.

In the inner surface (IS) case, higher WCA values were obtained for 1L-type scaffolds than the 2L-type. However, the differences were not statistically significant $(p>0.05)$.

For each analyzed material, the WCA values obtained for IS were lower than those obtained for OS.

\section{Mechanical properties}

The results of mechanical properties analysis are shown in Fig. 4. Materials were analyzed in the form of cylinders with an inner diameter of $3 \mathrm{~mm}$. It has been shown that both the morphology type and fiber diameter affect the mechanical properties of the materials. In both cases, 1L-type and 2L-type materials, the Young's modulus (Fig. 4C) value decreased with an increase of average fiber diameter. The highest Young's modulus value was obtained for materials composed of fibers with the lowest diameter $(1.8 \pm 0.3 \mathrm{MPa}$ for C75A_1L_200, $1.9 \pm$ $0.2 \mathrm{MPa}$ for C75A_2L_200). The values were statistically significantly different $(p<0.05)$ from the values obtained for other materials.

An inverse relationship was observed for the elongation at break values (Fig. 4D). Higher values were obtained for materials with higher average fiber diameter. Comparison of 1L-type and 2L-type materials shows that in most cases, values of elongation are higher for $1 \mathrm{~L}$ type materials. The exceptions are materials with the smallest average fiber diameter (C75A_200), where this relationship was inverse. The elongation values are about $300 \%$ for materials with average fiber diameter in the $500-1000 \mathrm{~nm}$ range and about $150 \%$ for materials with average fiber diameter in the $200-300 \mathrm{~nm}$ range.

A similar relationship presented itself for the tensile strength values (Fig. 4E). The values increased with the increase in the fiber's average diameter. This relationship was observed in both the 1L- and 2L-type groups. The highest values were obtained for materials composed of micron fibers $(3.5 \pm 0.3 \mathrm{MPa}$ for C75A_1L_900, $3.1 \pm 0.4 \mathrm{MPa}$ for C75A_2L_900). There were no statistically significant 

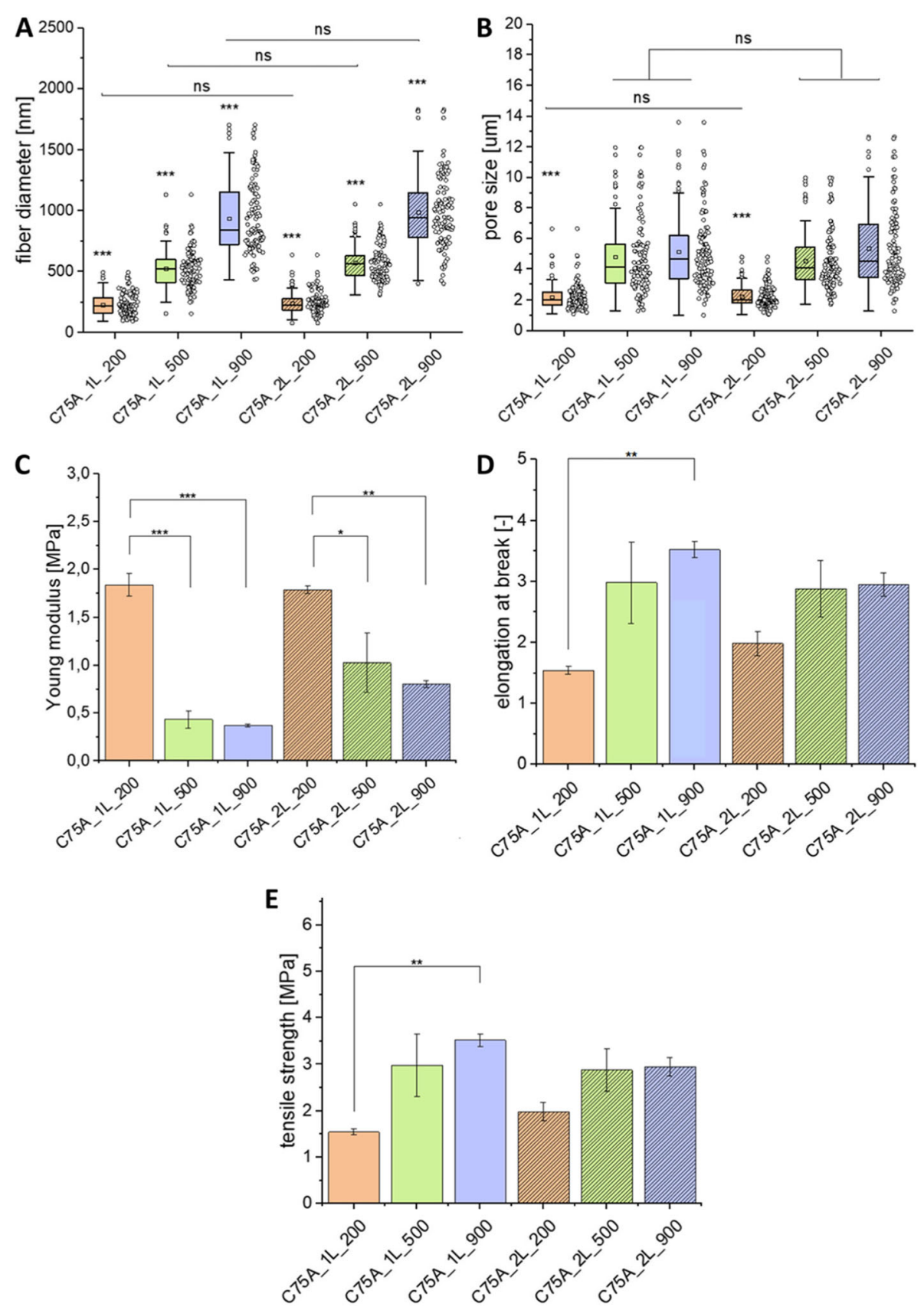

Fig. 4 Fiber diameter $(\mathbf{A})$ and pore size distribution (B). In the case of 2L-type materials, the values refer to the fibrous areas on the outer surface. ns - not significant, ${ }^{* * *} p<0.001$ vs. each other group. Mechanical properties of the analyzed materials: Young's modulus (C), elongation at break (D), and tensile strength (E). MV $\pm \mathrm{SD}, n=5,{ }^{*} p<0.05,{ }^{* *} p<0.01,{ }^{* * *} p<0.005$

differences in the tensile strength values between the analogous materials from the $1 \mathrm{~L}$ - and $2 \mathrm{~L}$-type groups.

\section{Endothelial cells growth}

\section{Endothelial cells viability}

ECs viability (Fig. 5A) after 1 day of culture on scaffolds' inner surface (IS) was similar for all types of analyzed samples. The viability values ranged from $66 \%$ (C75A 2L_900) to 78\% (C75A_2L_200). No relationship between surface morphology and the viability of the cells was observed.

After 7 days of culture, cell viability for most tested materials increased compared to the 1 day of culture. Only for C75A_2L_200, the viability decreased. The 
Table 3 Water contact angle values measured for inner (IS) and outer (OS) surfaces of the materials. MV $\pm S D, n=30$

\begin{tabular}{lll}
\hline Sample & OS water contact angle $\left[^{\circ}\right]$ & IS water contact angle $\left[^{\circ}\right]$ \\
\hline C75A_1L_200 & $122 \pm 2$ & $109 \pm 3$ \\
C75A_1L_500 & $127 \pm 4$ & $121 \pm 3$ \\
C75A_1L_900 & $130 \pm 3$ & $120 \pm 6$ \\
C75A_2L_200 & $123 \pm 4$ & $91 \pm 5$ \\
C75A_2L_500 & $121 \pm 7$ & $100 \pm 4$ \\
C75A_2L_900 & $125 \pm 3$ & $109 \pm 14$ \\
\hline
\end{tabular}

viability values were in the range from 68\% (C75A_2L_ 500) to $89 \%$ (C75A_2L_200).

After 1 day of culture, the amount of LDH released by cells growing on materials was lower than the amount of LDH released by the control (Fig. 5B). The lowest values were obtained for the $1 \mathrm{~L}$-type materials. The percentage of $\mathrm{LDH}$ release was in the range of $60-80 \%$. In the case of $2 \mathrm{~L}$-type materials, this ratio was $>80 \%$.
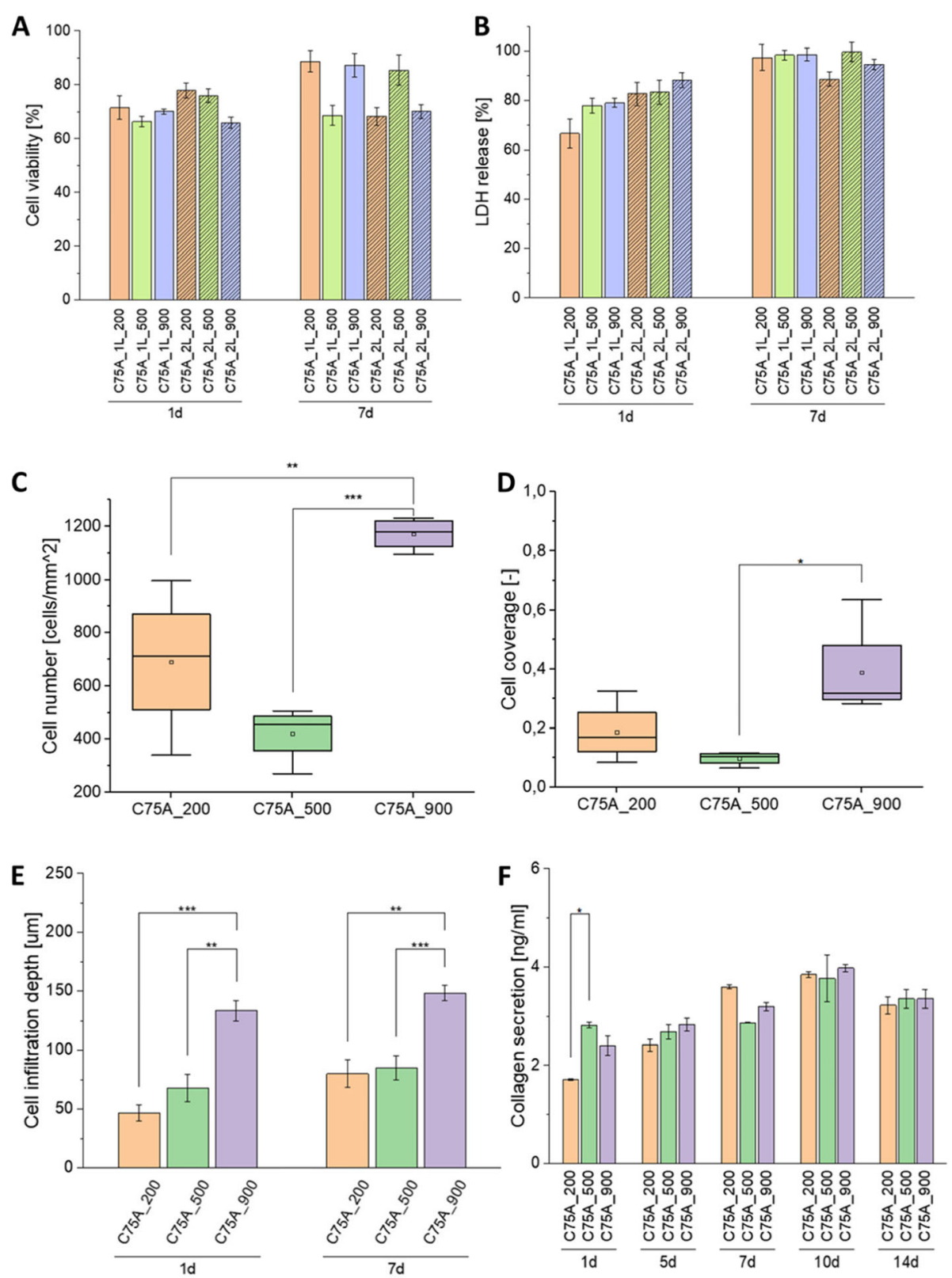

Fig. 5 Endothelial cell viability (A) and LDH assay (B) after 1 day and 7 days of ECs culture. MV $\pm S D, n=3$. Smooth muscle cell number (C) and cell coverage (D) obtained on the outer surface (OS) of the analyzed materials after 7 days of SMCs culture. SMCs infiltration depth after 1 and 7 days of culture (E). Collagen secretion after 1, 5, 7, 10 and 14 days of SMCs culture (F). MV \pm SD, $n>=3,{ }^{*} p<0.05,{ }^{* *} p<0.01,{ }^{* * *} p<0.005$ 
After 7 days of culture, the amount of released LDH was on a similar level for all 1L-type materials, and the values were slightly below $100 \%$. For the $2 \mathrm{~L}$-type materials, the LDH release was, in most cases, smaller; however, the differences were not statistically significant $(p>$ 0.05).

\section{Endothelial cells adhesion}

Figure 6 shows ECs growing on the inner surface (IS) of the analyzed materials after 1,3 , and 6 days of culture. The number of cells per $\mathrm{mm}^{2}$ and cell coverage are shown in Fig. 7.

After 1 day of culture, all analyzed materials presented surface-adhered cells with normal morphology. Cell growth was homogeneous - there were no areas with significantly fewer or more cells noticed. In the case of 1L-type materials, the number of cells per $\mathrm{mm}^{2}$ decreased with the increase of the average fiber diameter and was: $364 \pm 103$ cells $/ \mathrm{mm}^{2}$ for $\mathrm{C} 75 \mathrm{~A}$ 1L_200, $290 \pm 63$ cells $/ \mathrm{mm}^{2}$ for C75A_1L_500 and $233 \pm 188$ cells $/ \mathrm{mm}^{2}$ for C75A_1L_900 respectively. The same relationship was observed for 2L-type materials. The number of cells per $\mathrm{mm}^{2}$ was: $431 \pm 86$ cells $/ \mathrm{mm}^{2}$ for C75A_2L_200, $290 \pm 139$ cells $/ \mathrm{mm}^{2}$ for C75A_2L_500, and $227 \pm 193$ cells $/ \mathrm{mm}^{2}$ for C75A_ 2L_900 respectively. Again, the differences between the individual material variants were not statistically significant $(p>0.05)$. The values of cell coverage were similar for all tested surface variants and were smaller than 0.2. In the case of 1L-type materials, they were $0.19 \pm 0.05,0.19 \pm 0.02,0.14 \pm 0.03$ respectively for C75A_1L_200, C75A_1L_500, and C75A_1L_900. For 2L-type materials, the cell coverage was similar: $0.19 \pm 0.05,0.18 \pm 0.06,0.16 \pm 0.03$ for C75A_2L_200, C75A_2L_500, and C75A_2L_900 respectively.

After 3 days of culture, the number of cells per $\mathrm{mm}^{2}$ increased for all materials. On 1L-type materials, there was a decrease in the number of cells and the cell coverage with the increase in the average fiber diameter clearly visible. The number of cells per $\mathrm{mm}^{2}$ was: $757 \pm 131$ cells $/ \mathrm{mm}^{2}, 580 \pm 169$ cells $/ \mathrm{mm}^{2}, 497$ \pm 258 cells $/ \mathrm{mm}^{2}$ corresponding to C75A_1L_200, C75A_1L_500, and C75A_1L_900. The cell coverage was respectively: $0.48 \pm 0.04,0.37 \pm 0.09$, and $0.27 \pm$ 0.12 for C75A_1L_200, C75A_1L_500, and C75A_1L_ 900. The relationship was different for $2 \mathrm{~L}$-type materials. The number of cells per $\mathrm{mm}^{2}$ was similar for all three types of materials and amounted to: $600 \pm 313$ cells $/ \mathrm{mm}^{2}, 617 \pm 289$ cells $/ \mathrm{mm}^{2}, 603 \pm 439$ cells/ $\mathrm{mm}^{2}$, respectively for C75A_2L_200, C75A_2L_500, and C75A_2L_900. The values of cell coverage were also similar for all materials but showed great differentiation - there were areas with a large number of cells as well as areas without them. The values of cell coverage were slightly below 0.5 and amounted to: $0.48 \pm 0.26,0.49 \pm 0.28$, and $0.38 \pm 0.20$ for $\mathrm{C} 75 \mathrm{~A}$ 2L_200, C75A_2L_500, and C75A_2L_900, respectively.

After 6 days of culture, the differences in cell growth on individual materials were clearly visible. The highest cell coverage was obtained on the surfaces C75A_2L_200 $(0.57 \pm 0.15)$ and C75A_2L_500 $(0.66 \pm 0.09)$. Microscopic observations confirmed uniform cell growth on these surfaces. On 1L-type surfaces, the decrease in cell number and cell coverage with the increase of average fiber diameter was still maintained. The values of the number of cells per $\mathrm{mm}^{2}$ were: $804 \pm 208$ cells $/ \mathrm{mm}^{2}, 744 \pm 147$ cells/ $\mathrm{mm}^{2}, 585 \pm 158$ cells $/ \mathrm{mm}^{2}$ for C75A_1L_200, C75A 1L_500, and C75A_1L_900, respectively. The cell coverage was: $0.46 \pm 0.13,0.37 \pm 0.07$, and $0.27 \pm$ 0.07 for C75A_1L_200, C75A_1L_500, and C75A_1L_ 900 , respectively.

\section{Smooth muscle cells growth Smooth muscle cells adhesion and infiltration}

Figure 8 shows SMCs growing on the outer surface (OS) of the analyzed materials after 7 days of culture. The number of cells per $\mathrm{mm}^{2}$ and cell coverage are shown in Fig. $5 \mathrm{C}$ and D. As the outer surface (OS) for $1 \mathrm{~L}-$ and $2 \mathrm{~L}-$ type materials were produced in the same way, SMC culture was performed only for materials differing in average fiber diameter (designated as C75A_200, C75A_500, and C75A_900).

Analysis of SMCs growth on the materials' outer surface (OS) after 7 days of culture showed a significantly higher number of cells on the C75A_900 materials. The number of cells per $\mathrm{mm}^{2}$ was: $691 \pm 270$ cells $/ \mathrm{mm}^{2}, 422$ \pm 104 cells $/ \mathrm{mm}^{2}$ and $1172 \pm 61$ cells $/ \mathrm{mm}^{2}$ for C75A 200, C75A_500, and C75A_900, respectively. The cell coverage values were: $0.19 \pm 0.10,0.10 \pm 0.02$, and 0.39 \pm 0.17 for C75A_200, C75A_500, and C75A_900, respectively.

Figure 5E shows infiltration depth after 1 and 7 days of culture. Both after 1 and 7 days of culture, the infiltration depth was significantly higher for the C75A_900 material and amounted to $133 \pm 15 \mu \mathrm{m}$ and $148 \pm$ $16 \mu \mathrm{m}$ after 1 and 7 days of culture, respectively. For each of the tested materials, the infiltration depth after 7 days of culture was greater than the value achieved after 1 day.

\section{Collagen secretion}

The analysis of collagen secretion during the 14-day culture showed that during the first 10 days, the amount of secreted collagen increased for all analyzed material variants (Fig. 5F). On the 14th day of culture, the amount of 
A) $t=1$ day
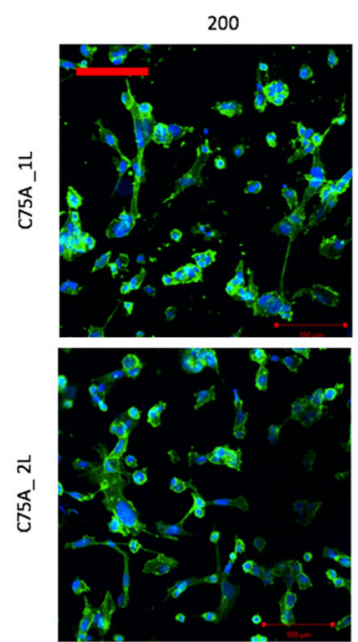

B) $t=3$ days
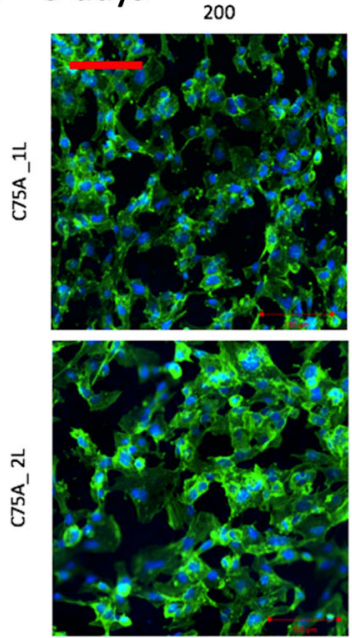

C) $t=6$ days

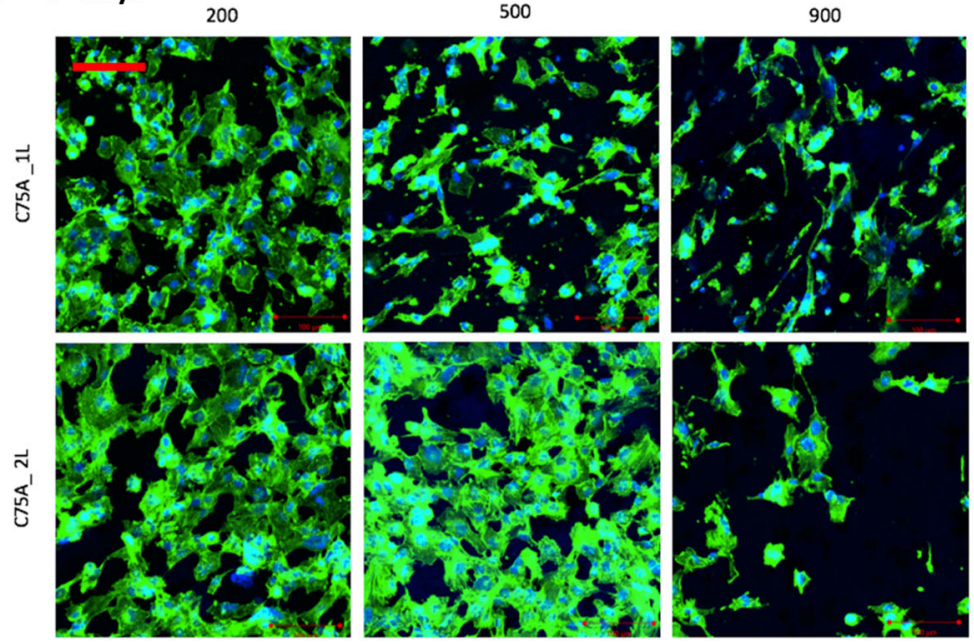

Fig. 6 ECs adhesion on the inner surface (IS) of the analyzed materials after 1 (A), 3 (B), and 6 (C) days of culture. Scale bar: 100 m 

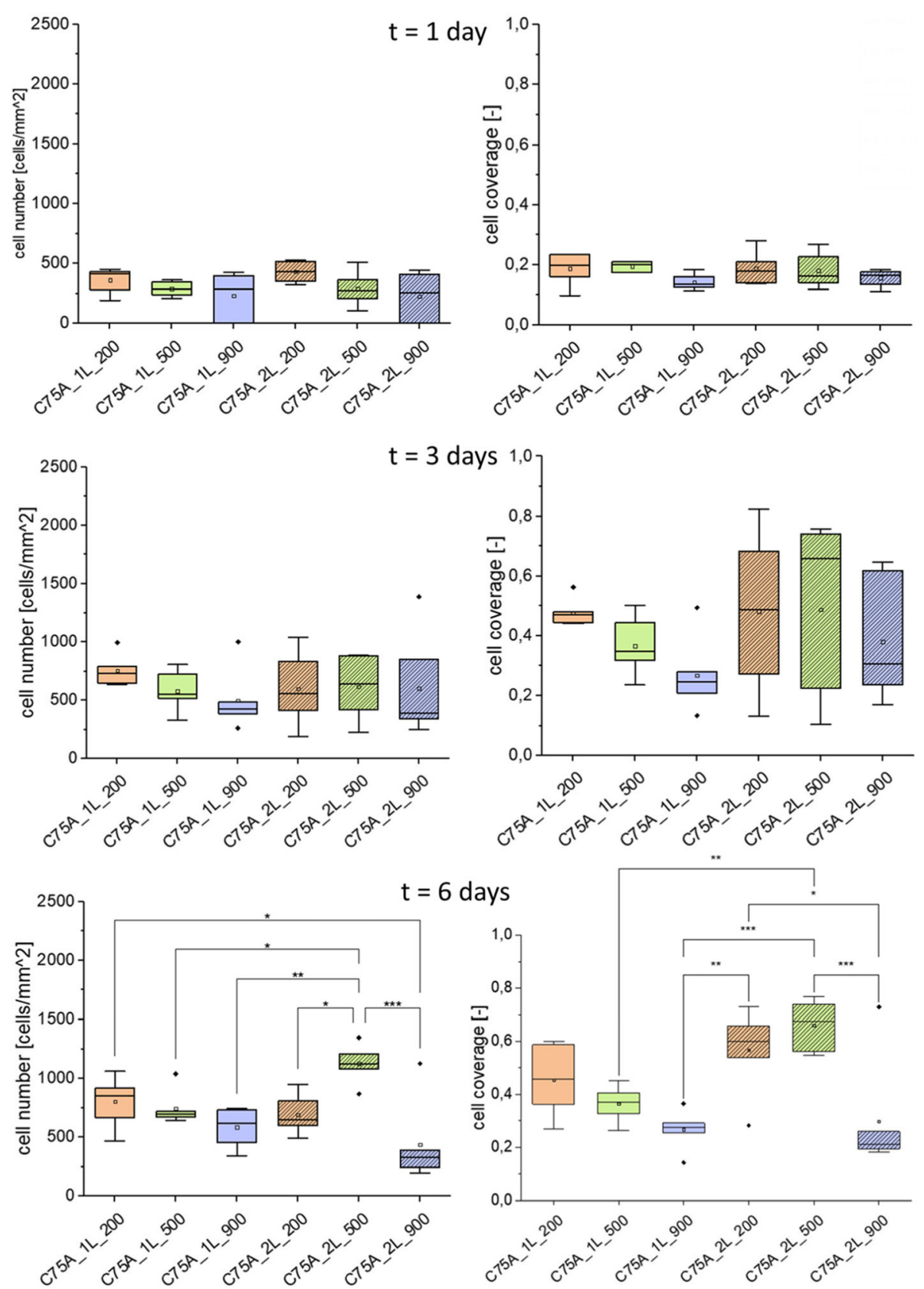

Fig. 7 Endothelial cell number and cell coverage obtained on the analyzed materials' inner surface (IS) after 1, 3, and 6 days of ECs culture. MV \pm SD, $n=6,{ }^{*} p<0.05,{ }^{* *} p<0.01,{ }^{* *} p<0.005$

collagen decreased compared to day 10 . On individual days, the differences between the material variants were minor and, in most cases, were not statistically significant. Only on the first day of culture, statistically significantly higher $(p<0.05)$ collagen secretion was obtained on the C75A_500 material $(2.82 \pm 0.08 \mathrm{ng} / \mathrm{ml})$ vs. C75A_200 $(1.72 \pm 0.02 \mathrm{ng} / \mathrm{ml})$. In the case of all analyzed materials, the highest values of secreted collagen were achieved on the 10th day of culture, and they were: $3.84 \pm 0.08 \mathrm{ng} / \mathrm{ml}, 3.76 \pm 0.67 \mathrm{ng} / \mathrm{ml}$, and $3.98 \pm 0.11$ ng/ml, respectively, for C75A_200, C75A_500, and C75A_900.

\section{Discussion}

The presented work aimed to determine the influence of the structure of fibrous scaffolds on the growth of two types of cells building blood vessels: ECs and SMCs. The materials were produced by the SBS technique using a medical-grade polyurethane solution. Design of the production process aimed at fabrication of one-layered and 


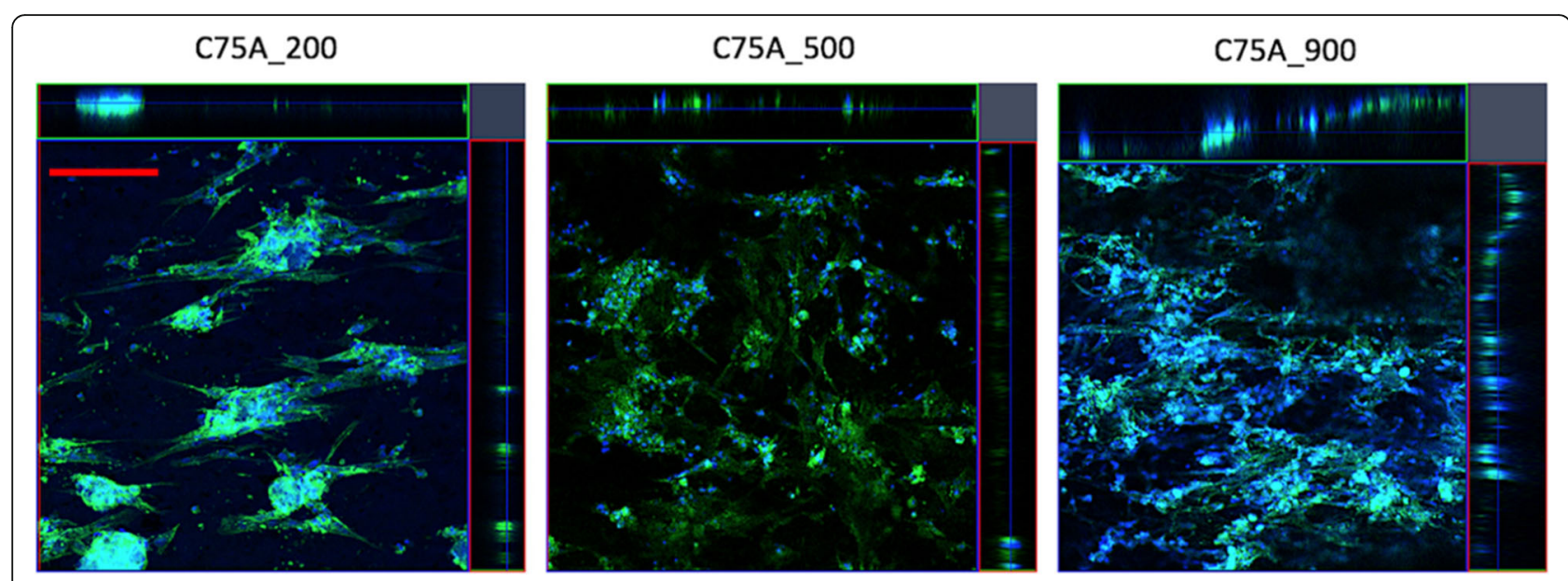

Fig. 8 SMCs adhesion after 7 days of culture on the analyzed materials' outer surface (OS). Scale bar: $100 \mu m$

bi-layered cylindrical scaffolds in one process, advantageous to other - two-step approaches [31, 32]. The produced materials in the form of cylinders were cut open, and two surfaces were separately analyzed. The growth of ECs was analyzed on the inner (collector side) surface, whereas the SMCs growth was analyzed on the outer surface.

Two types of material were prepared, differing in the morphology of the inner surface and the cross-section structure. The first type were fibrous materials of homogenous cross-section structure, designated as onelayer (1L). Scaffolds were produced with a constant nozzle-collector working distance of $30 \mathrm{~cm}$. The second type of materials presented variable structure. The inner surface consisted of non-fibrous (solid) areas and fibrous areas. Such a structure was obtained by reducing the nozzle-collector working distance $(10 \mathrm{~cm})$ during the production of the first inner layer. The second, fibrous outer layer, was produced with an increased nozzlecollector distance $(30 \mathrm{~cm})$. In this way, materials of variable structure, designated as bi-layer (2L), were obtained. Within each type, 3 groups of materials were produced, differing in the range of fiber and pore size. The first group obtained from the $2 \% \mathrm{w} / \mathrm{w}$ polymer solution was characterized by an average fiber diameter in the range of 200-300 $\mathrm{nm}$ and average pore size of approximately $2 \mu \mathrm{m}$. The second group obtained from the $4 \% \mathrm{w} / \mathrm{w}$ solution was characterized by an average fiber diameter in the range of 500-600 $\mathrm{nm}$ and average pore size of approximately $5 \mu \mathrm{m}$. The third group obtained from a $5 \%$ $\mathrm{w} / \mathrm{w}$ solution was characterized by an average fiber diameter in the range of $900-1000 \mathrm{~nm}$ and average pore size of approximately $5 \mu \mathrm{m}$. This evident influence of polymer solution concentration on fiber size and, consequently, on pore size was expected, as previously reported in the body of research concerning the solution blow spinning process [33-36]. Dependence of average fiber diameter on polymer concentration in solution allowed for the design of scaffolds for this study.

The culture of ECs was carried out for a week with observations after 1, 3, and 6 days of culture. The results showed that cell growth was similar on all types of materials after the first day of culture, regardless of the morphology. The fraction of the area occupied by the cells was approximately 0.2. After 3 days of culture, the number of cells on all materials increased, which confirmed the proper cell growth. There was also variation in the surface area occupied by cells depending on the type of material. In the group of 1L-type materials, a decrease in the number of cells was observed, along with an increase in the average fiber diameter. The same relationship was observed for the cell coverage. However, in the group of $2 \mathrm{~L}$-type materials, there was no difference in the number and cell coverage depending on the average diameter of the fibers. What is more, it was observed that the growth of cells was uneven - large standard deviations characterized both tested parameters. Microscopic analysis showed that the cells were mainly growing on fiber-free areas composed of a solid polymer film. The fibrous areas were characterized by a much smaller number of cells. After 6 days of culture on 1L-type materials, the relationship mentioned earlier was maintained - both the mean number of cells and the cell coverage increased as the average diameter of the fibers decreased. Greater differentiation appeared in the group of 2L-type materials. Statistically significant differences were obtained in both the number of cells and the cell coverage. The highest values were obtained for materials with average fiber diameter in the range of $200-300 \mathrm{~nm}$ and $500-600 \mathrm{~nm}$. For these materials, the values of cell coverage exceeded 0.6. For 2L-type materials with the largest average fiber diameter (900-1000 $\mathrm{nm}$ range), the smallest cell coverage (approximately 0.2 ) was observed. 
In the case of SMCs, the growth on the surface marked as outer was analyzed. It was assumed that this surface should be fibrous to promote SMCs infiltration and blood vessel formation. Therefore, in the case of the outer surface, mixed structures composed of solid and fibrous areas were not analyzed. As in the case of ECs, the growth of SMCs was investigated on surfaces with an average fiber diameter ranging from 200 to $300 \mathrm{~nm}$, $500-600 \mathrm{~nm}$, and $900-1000 \mathrm{~nm}$. The results clearly indicated that the best growth after 7 days of culture was obtained on the fibers with the largest diameters studied (900-1000 nm). The highest cell infiltration depth was also obtained for these materials, which can be attributed to the largest pore sizes among tested materials. At the same time, there were no significant differences in the amount of collagen secreted by SMCs growing on fibers of different diameters.

The study showed that the morphology of the materials significantly influences the rate of monolayer formation by ECs. The study aimed to select the inner surface of cylindrical blow spun scaffolds to obtain a fast rate of endothelial monolayer formation. In particular, the research aimed to compare one-layer structures made of fibers alone with bi-layer structures made of fibrous and solid areas.

Many studies show that cell growth is strongly dependent on the surface roughness, and in the case of fibrous materials, on the average diameter of the fibers. The nature of this relation depends on the type of cells. In the case of ECs growing on the surface of vascular prostheses, the main goal is to increase adhesion and create a monolayer on the prosthesis surface without the cells infiltrating the material. It has been shown that the increase of roughness at the nanoscale promotes adhesion of ECs [37]. A similar study was carried out for polylactide materials, which showed better growth of ECs on solid surfaces than fibrous ones [38]. Xu et al. suggests that the best solution in the case of vascular prostheses may be mixed structures created by combining solvent casting and electrospinning techniques. Most studies suggest better adhesion of ECs to nanofibers compared to microfibers. However, there are studies indicating the opposite relationship [39].

In the case of SMCs growth, many studies show that better growth is achieved on surfaces with higher roughness and larger average fiber diameter. Ju et al. showed that SMCs need fibers with an average diameter $>1 \mu \mathrm{m}$ for proper development and infiltration [12]. Han et al. showed that increasing the fiber diameter increases the infiltration of SMCs but reduces their proliferation [14].

It is worth mentioning that the morphology, particularly the roughness and the size of the fibers, also has a significant impact on the adhesion of blood components, particularly platelets [40], which is of crucial importance in the case of vascular prostheses. That is why it is essential to select the appropriate morphology in the design of modern, biocompatible vascular prostheses. The presented results clearly indicate that in the case of fibrous vascular prostheses, multilayer structures composed of fibers of various sizes and solid non-fibrous areas are a promising solution. We proved that the best growth of SMCs is obtained for micron fibers (with an average diameter in the $900-1000 \mathrm{~nm}$ range) compared to the submicron fibers (with an average diameter below $900 \mathrm{~nm}$ ). In the case of ECs, it seems that mixed structures composed of fibrous and solid areas are the best solution. Therefore, the best solution is a prosthesis consisting of a microfiber outer layer and a mixed inner layer containing fibrous and solid areas. Such a mixed, multilayer structure can be obtained using the SBS technique by appropriate selection of the process parameters (concentration of the polymer solution, working distance of the nozzle-collector). The solid regions promote the adhesion of ECs and accelerate the formation of the monolayer. On the other hand, the outer surface composed of micron fibers promotes the growth and infiltration of the SMCs.

\section{Conclusions}

Fibrous structures with different morphology were obtained using SBS technique. The materials differed in the average diameter of the fibers and the number of layers. The study investigated the effect of surface morphology on the growth of ECs and SMCs. In the case of ECs, we compared cell growth on fibrous surfaces (1L-type) with different average fiber diameters and mixed surfaces (2L-type) composed of solid and fibrous areas. ECs showed a higher cell coverage on mixed surfaces. These differences between surfaces became clearly visible after 6 days of culture. In the case of SMCs, better growth was shown on micron fibers compared to submicron fibers.

\section{Abbreviations}

EC: Endothelial cells, ES - electrospinning; IS: Inner surface; OS: Outer surface; SBS: Solution blow spinning; SMC: Smooth muscle cells

\section{Acknowledgements}

Not applicable.

\section{Authors' contributions}

I.Ł., A.K., P.T: methodology, investigation, writing - review \& editing, M.W.: conceptualization, methodology, investigation, writing - review \& editing, B.B-R.: conceptualization, methodology, investigation, formal analysis, resources, writing-original draft, visualization, supervision, project administration, funding acquisition. All authors read and approved the final manuscript.

\section{Funding}

The research was funded by the National Centre for Research and Development in Project Contract No. LIDER/18/0104/L-8/16/NCBR/2017. 


\section{Availability of data and materials}

Please contact author for data requests.

\section{Declarations}

Ethics approval and consent to participate

Not applicable.

\section{Consent for publication}

Not applicable.

\section{Competing interests}

The authors declare that they have no competing interests.

\section{Author details}

'Laboratory of Biomedical Engineering, Faculty of Chemical and Process Engineering, Warsaw University of Technology, Waryńskiego 1, 00-645 Warsaw, Poland. ${ }^{2}$ Centre for Advanced Materials and Technologies CEZAMAT, Warsaw University of Technology, Poleczki 19, 02-822 Warsaw, Poland.

\section{Received: 13 September 2021 Accepted: 14 November 2021} Published online: 19 December 2021

\section{References}

1. Zoghbi WA, Duncan T, Antman E, Barbosa M, Champagne B, Chen D, et al. Sustainable development goals and the future of cardiovascular health: a statement from the global cardiovascular disease taskforce. J Am Coll Cardiol. 2014;64(13):1385-7.

2. Williamson MR, Black R, Kielty C. PCL-PU composite vascular scaffold production for vascular tissue engineering: attachment, proliferation and bioactivity of human vascular endothelial cells. Biomaterials. 2006;27(19): 3608-16.

3. Norgren L, Hiatt WR, Dormandy JA, Nehler MR, Harris KA, Fowkes FGR. Intersociety consensus for the management of peripheral arterial disease (TASC II). J Vasc Surg. 2007;45:S5-67.

4. Pashneh-Tala S, MacNeil S, Claeyssens F. The tissue-engineered vascular graft - past, present, and future. Tissue Eng - Part B Rev. 2016;22(1):68-100.

5. McKenna KA, Hinds MT, Sarao RC, Wu PC, Maslen CL, Glanville RW, et al. Mechanical property characterization of electrospun recombinant human tropoelastin for vascular graft biomaterials. Acta Biomater. 2012;8(1):225-33.

6. Wise SG, Byrom MJ, Waterhouse A, Bannon PG, Ng MKC, Weiss AS. A multilayered synthetic human elastin/polycaprolactone hybrid vascular graft with tailored mechanical properties. Acta Biomater. 2011:7(1):295-303.

7. Abruzzo A, Fiorica C, Palumbo VD, Altomare R, Damiano G, Gioviale MC, et al. Using polymeric scaffolds for vascular tissue engineering. Int J Polym Sci. 2014. https://doi.org/10.1155/2014/689390

8. Rustad KC, Sorkin M, Levi B, Longaker MT, Gurtner GC. Strategies for organ level tissue engineering. Organogenesis. 2010;6:151-7.

9. De Mel A, Murad F, Seifalian AM. Nitric oxide: a guardian for vascular grafts? Chem Rev. 2011;111(9):5742-67.

10. Hollister SJ. Porous scaffold design for tissue engineering. Nat Mater. 2005; 4(7):518-24.

11. Wang W, Nie W, Zhou X, Feng W, Chen L, Zhang Q, et al. Fabrication of heterogeneous porous bilayered nanofibrous vascular grafts by two-step phase separation technique. Acta Biomater. 2018;79:168-81.

12. Ju YM, Choi JS, Atala A, Yoo JJ, Lee SJ. Bilayered scaffold for engineering cellularized blood vessels. Biomaterials. 2010;31(15):4313-21. Available from: https://doi.org/10.1016/j.biomaterials.2010.02.002

13. Singh R, Eitler D, Morelle R, Friedrich RP, Dietel B, Alexiou C, et al. Optimization of cell seeding on electrospun PCL-silk fibroin scaffolds. Eur Polym J. 2020;134: 109838. https://doi.org/10.1016/j.eurpolymj.2020.109838

14. Han DG, Ahn CB, Lee JH, Hwang Y, Kim JH, Park KY, et al. Optimization of electrospun poly(caprolactone) fiber diameter for vascular scaffolds to maximize smooth muscle cell infiltration and phenotype modulation. Polymers. 2019:11(4):643. https://doi.org/10.3390/polym11040643.

15. Reid JA, McDonald A, Callanan A. Electrospun fibre diameter and its effects on vascular smooth muscle cells. J Mater Sci Mater Med. 2021:32(10):131. https://doi.org/10.1007/s10856-021-06605-8.

16. Matsuzaki Y, Iwaki R, Reinhardt JW, Chang YC, Miyamoto S, Kelly J, et al. The effect of pore diameter on neo-tissue formation in electrospun biodegradable tissue-engineered arterial grafts in a large animal model. Acta Biomater. 2020:115:176-84.

17. Goins A, Webb AR, Allen JB. Multi-layer approaches to scaffold-based small diameter vessel engineering: a review. Mater Sci Eng C. 2019;97(November 2018):896-912.

18. Hasan A, Memic A, Annabi N, Hossain M, Paul A, Dokmeci MR, et al. Electrospun scaffolds for tissue engineering of vascular grafts. Acta Biomater. 2014;10(1):11-25. Available from: https://doi.org/10.1016/j.actbio.2 013.08.022.

19. Elsayed Y, Lekakou C, Labeed F, Tomlins P. Fabrication and characterisation of biomimetic, electrospun gelatin fibre scaffolds for tunica mediaequivalent, tissue engineered vascular grafts. Mater Sci Eng C. 2016;61:47383. Available from: https://doi.org/10.1016/j.msec.2015.12.081.

20. McClure MJ, Sell SA, Simpson DG, Walpoth BH, Bowlin GL. A threelayered electrospun matrix to mimic native arterial architecture using polycaprolactone, elastin, and collagen: a preliminary study. Acta Biomater. 2010;6(7):2422-33. Available from: https://doi.org/10.1016/j.a ctbio.2009.12.029

21. Ye L, Cao J, Chen L, Geng X, Zhang A-Y, Guo L-R, et al. The fabrication of double layer tubular vascular tissue engineering scaffold via coaxial electrospinning and its 3D cell coculture. J Biomed Mater Res A. 2015; 103(12):3863-71. https://doi.org/10.1002/jbm.a.35531.

22. Browning MB, Dempsey D, Guiza V, Becerra S, Rivera J, Russell B, et al. Multilayer vascular grafts based on collagen-mimetic proteins. Acta Biomater. 2012;8(3):1010-21. Available from: https://doi.org/10.1016/j.a ctbio.2011.11.015

23. Zhang F, Xie Y, Celik H, Akkus O, Bernacki SH, King MW. Engineering smallcaliber vascular grafts from collagen filaments and nanofibers with comparable mechanical properties to native vessels. Biofabrication. 2019; 11(3):035020. https://doi.org/10.1088/1758-5090/ab15ce.

24. Soletti L, Hong Y, Guan J, Stankus JJ, El-Kurdi MS, Wagner WR, et al. A bilayered elastomeric scaffold for tissue engineering of small diameter vascular grafts. Acta Biomater. 2010;6(1):110-22. Available from: http://www. pubmedcentral.nih.gov/articlerender.fcgi?artid=3200232\&tool= pmcentrez\&rendertype=abstract.

25. François $\mathrm{S}$, Chakfé $\mathrm{N}$, Durand $\mathrm{B}$, Laroche $\mathrm{G}$. A poly(L-lactic acid) nanofibre mesh scaffold for endothelial cells on vascular prostheses. Acta Biomater. 2009;5(7):2418-28. Available from: http://www.ncbi.nlm.nih.gov/pubmed/1 9345622.

26. Akentjew TL, Terraza C, Suazo C, Maksimuck J, Wilkens CA, Vargas F, et al. Rapid fabrication of reinforced and cell-laden vascular grafts structurally inspired by human coronary arteries. Nat Commun. 2019;10(1):1-16. Available from: https://doi.org/10.1038/s41467-019-11090-3.

27. Wojasiński M, Pilarek M, Ciach T. Comparative studies of electrospinning and solution blow spinning processes for the production of nanofibrous poly $(\mathrm{L}-$ Lactic Acid) materials for biomedical engineering. Polish J Chem Technol. 2014;16(2):43-50.

28. Schindelin J, Arganda-carreras I, Frise E, Kaynig V, Longair M, Pietzsch T, et al. Fiji: an open-source platform for biological-image analysis. Nat Methods. 2012;9(7):676-82. https://doi.org/10.1038/nmeth.2019.

29. Tomecka E, Wojasinski M, Jastrzebska E, Chudy M, Ciach T, Brzozka Z. Poly(Llactic acid) and polyurethane nanofibers fabricated by solution blow spinning as potential substrates for cardiac cell culture. Mater Sci Eng C. 2017;75:305-16

30. Łopianiak I, Wojasiński M, Butruk-Raszeja B. Properties of polyurethane fibrous materials produced by solution blow spinning. Chem Process Eng. 2020;41(4):267-76.

31. Mi HY, Jing $X, Y u E$, McNulty J, Peng XF, Turng LS. Fabrication of triplelayered vascular scaffolds by combining electrospinning, braiding, and thermally induced phase separation. Mater Lett. 2015;161:305-8. Available from: https://doi.org/10.1016/j.matlet.2015.08.119.

32. Al Kayal T, Maniglio D, Bonani W, Losi P, Migliaresi C, Soldani G. A combined method for bilayered vascular graft fabrication. J Mater Sci Mater Med. 2015; 26(2):96. https://doi.org/10.1007/s10856-015-5458-7.

33. Yang Z, Peng H, Wang W, Liu T. Nano and submicrometric fibers of poly(D,L-lactide) obtained by solution blow spinning: process and solution blow spinning: process and solution variables. J Appl Polym Sci. 2010;116(5): 2658-67.

34. Da Silva Parize DD, De Oliveira JE, Foschini MM, Marconcini JM, Mattoso LHC. Poly(lactic acid) fibers obtained by solution blow spinning: effect of a greener solvent on the fiber diameter. J Appl Polym Sci. 2016;133(18):1-10. 
35. Lou H, Li W, Li C, Wang X. Systematic investigation on parameters of solution blown micro/nanofibers using response surface methodology based on box-Behnken design. J Appl Polym Sci. 2013;130(2):1383-91.

36. Czarnecka K, Wojasiński M, Ciach T, Sajkiewicz P. Solution blow spinning of polycaprolactone-rheological determination of spinnability and the effect of processing conditions on fiber diameter and alignment. Materials. 2021; 14(6):1463. https://doi.org/10.3390/ma14061463.

37. Chung TW, Liu DZ, Wang SY, Wang SS. Enhancement of the growth of human endothelial cells by surface roughness at nanometer scale. Biomaterials. 2003;24(25):4655-61.

38. Xu C, Yang F, Wang S, Ramakrishna S. In vitro study of human vascular endothelial cell function on materials with various surface roughness. J Biomed Mater Res - Part A. 2004;71(1):154-61.

39. Rüder C, Sauter T, Kratz K, Haase T, Peter J, Jung F, et al. Influence of fibre diameter and orientation of electrospun copolyetheresterurethanes on smooth muscle and endothelial cell behaviour. Clin Hemorheol Microcirc. 2013;55(4):513-22.

40. Milleret V, Hefti T, Hall H, Vogel V, Eberli D. Influence of the fiber diameter and surface roughness of electrospun vascular grafts on blood activation. Acta Biomater. 2012;8(12):4349-56. Available from: https://doi.org/10.1016/j.a ctbio.2012.07.032.

\section{Publisher's Note}

Springer Nature remains neutral with regard to jurisdictional claims in published maps and institutional affiliations.

Ready to submit your research? Choose BMC and benefit from:

- fast, convenient online submission

- thorough peer review by experienced researchers in your field

- rapid publication on acceptance

- support for research data, including large and complex data types

- gold Open Access which fosters wider collaboration and increased citations

- maximum visibility for your research: over $100 \mathrm{M}$ website views per year

At BMC, research is always in progress.

Learn more biomedcentral.com/submissions 